\title{
ASSESSMENT OF HYDROPHOBICITY AND ROUGHNESS OF STAINLESS STEEL ADHERED BY AN ISOLATE OF BACILLUS CEREUS FROM A DAIRY PLANT
}

\author{
Patrícia Campos Bernardes ${ }^{1}$, Nélio José de Andrade ${ }^{1 *}$, Sukarno Olavo Ferreira ${ }^{2}$, João Paulo Natalino de Sá1, Emiliane \\ Andrade Araújo ${ }^{1}$, Deyse Maria Zanom Delatorre ${ }^{1}$, Lívia Maria Pinheiro Luiz ${ }^{1}$ \\ ${ }^{1}$ Departamento de Tecnologia de Alimentos, Universidade Federal de Viçosa, Viçosa, MG, Brasil; ${ }^{2}$ Departamento de Física, \\ Universidade Federal de Viçosa, Viçosa, MG, Brasil.
}

Submitted: May 15, 2009; Returned to authors for corrections: April 04, 2010; Approved: April 26, 2010.

\begin{abstract}
The interaction between the surface of stainless steel and Bacillus cereus was studied in terms of the characteristics of interfacial interaction determined from the measurement of the contact angle of the surface of B. cereus and stainless steel in the presence or absence of B. cereus adherence. The microtopographies and the roughness of the surface of stainless steel and stainless steel adhered by $B$. cereus were evaluated with the help of atomic force microscopy and perfilometry. The strain of B. cereus studied was considered hydrophilic, whereas the stainless steel was considered hydrophobic. The adhesion was not thermodynamically favorable $\left(\Delta \mathrm{G}_{\text {adhesion }}>0\right)$ between the stainless steel and the strain of B. cereus studied. Thus, the interaction between them was not favored by the thermodynamic aspect of adhesion. There was no difference $(\mathrm{p}>0.05)$ in the roughness of the surfaces of stainless steel adhered by $B$. cereus when analyzed by atomic force microscope and perfilometry.
\end{abstract}

Key words: hydrophobicity, roughness, Bacillus cereus, dairy plant, adhesion.

\section{INTRODUCTION}

Bacillus cereus, a spore forming bacterium, is an inevitable low-grade contaminant of a wide variety of foods, including cereals, food additives and processed milk products $(11,14)$. Due to high incidence in these products, some outbreaks have been reported in which milk or milk-related products containing $B$. cereus were suggested to be the cause of disease $(2,14)$. Also, B. cereus isolates has been observed in a high number of samples collected from food processing contact surfaces in the dairy industry (2). The occurrence of these microorganisms in pasteurized milk can be explained by the presence of their heat-resistance spores in raw milk or by milk recontamination, due to inadequately cleaned and sanitized surfaces $(3,9,13)$. The main consequence of $B$. cereus contamination in milk is the decreasing of shelf life and the occurrence of an off-flavor (9). B. cereus produces thermoresistant extracellular proteases and phospholipases that cause sweet coagulation and bitterness defects in milk.

Bacterial adhesion of $B$. cereus and other microorganisms to food processing contact surfaces is affected by the interaction of physicochemical characteristics of the microorganism surface and the contact surfaces. Specific linkages between microorganisms and food processing surfaces depend on the chemical composition of the both surfaces (17). Surfaces characteristics including cell surface hydrophobicity 
relative surface charge have been reported to affect the adhesion of bacteria. The prediction of bacterial adhesion based on physicochemical factors was initially studied using the DLVO theory, first proposed by Derjaguin and Landau in 1941 and complemented by Verwey and Overbeek in 1948 (15). DLVO theory was proposed for liophobic colloidal particles, considering only long forces such as van der Waals forces. In 1994, van Oss and co-workers (19) proposed the extended DLVO theory that includes the influence of short forces such as Born repulsion forces, hydration forces, hydrophobic interactions and polymer bridges. However, it is important to mention that cellular structures such as flagella, fimbriae, and pili, and that the production of extracellular polysaccharides plays an important role in the adhesion process. In addition, environmental conditions such as $\mathrm{pH}$, ionic forces, temperature, exposure time and cellular concentration of microorganisms strongly influence the adhesion process (6). Better understanding of the role of physicochemical properties in the adhesion process and biofilm formation on food processing contact surfaces can aid in the control of bacterial growth in environmental milk processing at dairy plants.

In the present study, the characteristics of interfacial tension of an isolated $B$. cereus strain from a dairy plant, a stainless steel surface and a stainless steel surface adhered by B. cereus were examined by measurements of contact angles between the surfaces and applying the data to the extendedDLVO theory. In addition, the roughness and the microtopography of stainless steel surfaces were evaluated in the presence or absence of $B$. cereus adherence.

\section{MATERIALS AND METHODS}

\section{Microorganism and Surfaces}

Studies were conducted using suspensions a B. cereus strain isolated from the surface of a stainless steel pasteurized milk packaging machine that was identified as Ribo 1222173 $\mathrm{S} 4$. Surfaces of coupons $(10 \mathrm{~mm} \times 10 \mathrm{~mm} \times 0.5 \mathrm{~mm})$ of stainless steel AISI 304, \#4, in the presence or absence of $B$. cereus adherence, were used for bacterial adherence studies.
One milliliter of the culture was stored at $-80^{\circ} \mathrm{C}$ in nutrient broth (Merck, Sao Paulo, Brazil) containing glycerol (80:20). A working culture of the strain containing approximately $10^{7}$ $\mathrm{cfu} / \mathrm{mL}$ was prepared by inoculation of $100 \mu \mathrm{L}$ of frozen culture into $10 \mathrm{~mL}$ of Brain Hearth Infusion (BHI, Merck, São Paulo, Brazil), followed by incubation at $32^{\circ} \mathrm{C}$ for $24 \mathrm{~h}$. The culture was sub-cultured two times before use. The number of microorganisms in each suspension was obtained by total count using Plate Count Agar (PCA, Merck, São Paulo, Brazil) at $32^{\circ} \mathrm{C}$ for $24 \mathrm{~h}$.

\section{Attachment of Cells}

Coupons were first cleaned by washing them with neutral liquid detergent and water, followed by rinsing with distilled water and immersion in $70 \%$ ethyl alcohol for $1 \mathrm{~h}$ to remove fat. Subsequently, coupons were rinsed with distilled water, air-dried, and sterilized at $121^{\circ} \mathrm{C}$ for $15 \mathrm{~min}$ (12). The cleaned and sanitized coupons were added to $250 \mathrm{~mL}$ flasks containing $100 \mathrm{~mL}$ of nutrient broth, which were previously inoculated with suspensions of $B$. cereus. The initial number of cells was approximately $10^{3} \mathrm{cfu} / \mathrm{mL}$, and the flasks were incubated statically for different times and at different temperatures according to the full factorial at two levels (Table 1).

At the proper times, coupons were removed and rinsed for $1 \mathrm{~min}$ in tubes containing $10 \mathrm{~mL}$ of sterilized $0.1 \%$ peptone water to remove the planktonic cells. Afterward, each coupon was placed into Petri plates and analyzed for contact angle and roughness.

Table 1. Temperature and time of adherence of Bacillus cereus on the surface of stainless steel.

\begin{tabular}{ccc}
\hline Experiments & Time (days) & Temperature $\left({ }^{\circ} \mathbf{C}\right)$ \\
\hline E1 & 1 & $4^{\circ} \mathrm{C}$ \\
E2 & 1 & $10^{\circ} \mathrm{C}$ \\
E3 & 1 & $25^{\circ} \mathrm{C}$ \\
E4 & 1 & $35^{\circ} \mathrm{C}$ \\
E5 & 5.5 & $7^{\circ} \mathrm{C}$ \\
E6 & 5.5 & $15^{\circ} \mathrm{C}$ \\
E7 & 5.5 & $20^{\circ} \mathrm{C}$ \\
E8 & 5.5 & $30^{\circ} \mathrm{C}$ \\
E9 & 10 & $4^{\circ} \mathrm{C}$ \\
E10 & 10 & $10^{\circ} \mathrm{C}$ \\
E11 & 10 & $25^{\circ} \mathrm{C}$ \\
E12 & 10 & $35^{\circ} \mathrm{C}$ \\
\hline
\end{tabular}




\section{Contact Angle Measurement}

For stainless steel AISI 304, \#4 and stainless steel AISI 304 \# 4 adhered by B. cereus, the contact angles between the surfaces and water, formamide, and $\alpha$-bromonaphthalene were determined using a goniometer (Kruss, Germany). Measurements of the contact angle of one $2.0 \mu \mathrm{L}$ drop were taken each second for $30 \mathrm{~s}$ for all liquids and surfaces. Experiments were conducted in triplicate. The contact angle for the microorganism surface was determined on a layer of vegetative cells using the drop method (5). First, the strain of B. cereus was activated twice in BHI broth (Merck, Sao Paulo, Brazil), creating suspensions with approximately $10^{7} \mathrm{CFU} / \mathrm{mL}$. The suspensions were centrifuged at $12.000 \mathrm{~g}$ for $10 \mathrm{~min}$ and washed three times in $0.1 \mathrm{M}$ phosphate buffered saline (PBS). The cell pellet was suspended in the same buffer, and the suspension was filtered using an acetate cellulose membrane (0.45 $\mu \mathrm{m}$ pore size, $27 \mathrm{~mm}$ in diameter) using negative pressure. During the filtration, $30 \mathrm{~mL}$ of pure water (Milli-Q) were added. The membranes were transferred to Petri plates containing $1 \%(\mathrm{v} / \mathrm{v})$ agar and $10 \%(\mathrm{v} / \mathrm{v})$ glycerol. The membranes were cut into three parts for contact angle measurements with water, formamide, and $\alpha$ bromonaphthalene.

\section{Determination of the Total Interfacial Tension $\left(\gamma^{\text {tot }}\right)$}

The equation of Young-Good-Girifalco-Fowkes (Equation 1) relates the contact angle formed by the liquid above a solid surface with the components of interfacial tension of liquids $\left(\gamma_{1}\right.$ LW $\left., \gamma_{1}{ }^{+}, \gamma_{1}{ }^{-}\right)$and of the surface $\left(\gamma_{\mathrm{s}}{ }^{\mathrm{LW}}, \gamma_{\mathrm{s}}{ }^{+},{\gamma_{\mathrm{s}}}^{-}\right)$as follows:

$$
\begin{aligned}
\left(1+\cos \theta_{B}\right) \gamma_{l}^{T O T}= & 2\left(\sqrt{\gamma_{s}^{L W} \gamma_{l}^{L W}}+\sqrt{\gamma_{s}^{+} \gamma_{l}^{-}}+\sqrt{\gamma_{s}^{-} \gamma_{l}^{+}}\right) \\
& \text {Equation }(1)
\end{aligned}
$$

where $\gamma^{\text {tot }}$ is the total interfacial tension of the surface, $\gamma^{\mathrm{LW}}$ is the interfacial tension of the interactions of the Lifshitz-van der Waals forces, $\gamma^{\mathrm{AB}}$ is the polar component of the Lewis acidbase interaction, $\gamma^{+}$is the interfacial tension of the electron acceptor component of the acid-base component, $\gamma^{-}$is the interfacial tension of electron donor component of the acidbase component, $\Theta_{B}$ is the contact angle obtained with $\alpha$ bromonaphthalene and $s$ and $l$ indicate surface and liquid, respectively (19).

The three components of the interfacial tension of the surfaces were determined from the contact angles obtained from three liquids with different polarities, whose interfacial tensions are known as shown in Table 2.

Table 2. Interfacial tension components of liquids at $25^{\circ} \mathrm{C}$.

\begin{tabular}{cllcc}
\hline \multirow{2}{*}{ Liquid } & \multicolumn{4}{c}{ Interfacial tension $\left(\mathbf{m} \mathbf{J} / \mathbf{m}^{\mathbf{2}}\right)$} \\
\cline { 2 - 5 } & $\gamma_{1}{ }^{\text {Tot }}$ & $\gamma_{1}{ }^{\text {LW }}$ & $\gamma_{1}{ }^{+}$ & $\gamma_{1}{ }^{-}$ \\
\hline$\alpha$-Bromonaphthalene & 44.4 & 44.4 & 0.0 & 0.0 \\
Water & 72.8 & 21.8 & 25.5 & 25.5 \\
Formamide & 58.0 & 39.0 & 2.28 & 39,6 \\
\hline Source: (18) & &
\end{tabular}

Source: (18)

The interfacial tension is equal to the sum of the two components $\left(\gamma_{\mathrm{s}}{ }^{\mathrm{LW}}\right.$ and $\left.\gamma_{\mathrm{s}}^{\mathrm{AB}}\right)$ :
a) $\gamma_{s}^{L W}=11.1\left(1+\cos \theta_{B}\right)^{2}$ Equation (2)
b) $\gamma_{s}^{A B}=2 \sqrt{\gamma_{s}^{+} \gamma_{s}^{-}}$Equation (3)
c) $\gamma_{s}^{t o t}=\gamma_{s}^{L W}+\gamma_{s}^{A B}$ Equation (4)

Total Free Energy of Interaction $\left(\Delta \mathrm{G}_{\mathrm{sws}}{ }^{\mathrm{TOT}}\right)$

The total free energy of interaction among molecules of the surface(s) immersed in water (w) is determined by the sum of the apolar and polar free energies of interaction, $\Delta \mathrm{G}_{\mathrm{sws}}{ }^{\mathrm{LW}}$ and $\Delta \mathrm{G}_{\mathrm{sws}}{ }^{\mathrm{AB}}$, respectively.

$$
\begin{aligned}
& \Delta G_{s w s}^{T O T}=\Delta G_{s w s}^{L W}+\Delta G_{s w s}^{A B} \text { Equation (5) } \\
& \Delta G_{s w s}^{L W}=-2 x \sqrt{\gamma_{s}^{L W}-\gamma_{w}^{L W}} \text { Equation (6) }
\end{aligned}
$$


$\Delta G_{s w s}^{A B}=-4\left(\sqrt{\gamma_{s}^{+} \gamma_{s}^{-}}+\sqrt{\gamma_{w}^{+} \gamma_{w}^{-}}-\sqrt{\gamma_{s}^{+} \gamma_{w}^{-}}-\sqrt{\gamma_{w}^{+} \gamma_{s}^{-}}\right)$

Equation (7)

When $\Delta \mathrm{G}_{\mathrm{sws}}{ }^{\text {TOT }}>, 0$ the surface is considered hydrophilic. Conversely, if $\Delta \mathrm{G}_{\mathrm{sws}}{ }^{\text {TOT }}<0$, the surface is considered hydrophobic.

Determination of the Total Free Energy of Adhesion $\left(\Delta \mathrm{G}_{\mathrm{adhesion}}\right)$

From the values of the components of the interfacial tensions, it is possible to determine the $\Delta \mathrm{G}_{\text {adhesion }}$ between two surfaces (microbial cells (b) and food processing surfaces (s)):

$\gamma_{b s}=\gamma_{b s}^{L W}+\gamma_{b s}^{A B}$ Equation (8)

$\gamma_{b s}^{L W}=\gamma_{b}^{L W}+\gamma_{s}^{L W}-2 \sqrt{\gamma_{b}^{L W} \gamma_{s}^{L W}}$ Equation (9)

$\gamma_{b s}^{A B}=2\left(\sqrt{\gamma_{b}^{+} \gamma_{b}^{-}}+\sqrt{\gamma_{s}^{+}} \gamma_{s}^{-}-\sqrt{\gamma_{b}^{+} \gamma_{s}^{-}}-\sqrt{\gamma_{b}^{-}} \gamma_{s}^{+}\right)$

Equation (10)

When free energy is related to the interfacial tension, then $\Delta \mathrm{G}_{\text {adhesion }}$ can be represented by the following:

$\Delta G_{\text {adhesion }}=\Delta G_{b l s}^{L W}+\Delta G_{b l s}^{A B}$ Equation (11)

$\Delta G_{b l s}^{L W}=\gamma_{b s}^{L W}-\gamma_{b l}^{L W}-\gamma_{s l}^{L W} \quad$ Equation (12)

$\Delta G_{b l s}^{A B}=\gamma_{b s}^{A B}-\gamma_{b l}^{A B}-\gamma_{s l}^{A B} \quad$ Equation (13)

where $\gamma_{\mathrm{bs}}$ is the interfacial tension between the bacterial surfaces and the adhesion surface, $\gamma_{\mathrm{bl}}$ is the interfacial tension between the bacterial surfaces and the liquid, and $\gamma_{\mathrm{sl}}$ is the interfacial tension between the adhesion surfaces and the liquid. The $\Delta \mathrm{G}_{\text {adhesion }}$ values allow for evaluation of the thermodynamics of the adhesion process: if $\Delta \mathrm{G}_{\text {adhesion }}<0$, the process is favorable, but if $\Delta \mathrm{G}_{\text {adhesion }}>0$, the process is unfavorable.

\section{Surface Roughness}

The microtopography of the stainless surface in the presence or absence of $B$. cereus adherence was evaluated using atomic force microscopy (AFM)that analyzed areas of $100 \mu^{2}$ and $10 \mu \mathrm{m}^{2}$ (Universal SPM System Ntegra Prima/NT-MDT) and using a Perthometer (Ambios Technology, XP1) that analyzed one line of $1 \mathrm{~mm}$ in each coupon. The experiment was conducted with three repetitions. The roughness of the surfaces was compared before and after bacterial adhesion by different numbers of $B$. cereus by regression analysis at $5 \%$ of probability. The means of the roughness were submitted to Tukey's test $(\alpha=0.05)$ by using the Statistical Analysis System (SAS), version 9.1.

\section{RESULTS AND DISCUSSION}

\section{Adhesion of B. cereus}

The numbers $\left(\log \mathrm{cfu} / \mathrm{cm}^{2}\right)$ of Bacillus cereus cells adhered to stainless steel AISI 304 \#4 in different experiments are shown in Table 3.

Table 3. Number $\left(\log \mathrm{cfu} / \mathrm{cm}^{2}\right)$ of Bacillus cereus cells adhered to stainless steel AISI 304 \#4 in different experiments.

\begin{tabular}{lc}
\hline Experiments & Log cfu/cm \\
\hline E1 $\left(4^{\circ} \mathrm{C} / 1 \mathrm{~d}\right)$ & $0.91 \pm 0.66$ \\
$\mathrm{E} 2\left(10^{\circ} \mathrm{C} / 1 \mathrm{~d}\right)$ & $1.40 \pm 1.00$ \\
$\mathrm{E} 3\left(25^{\circ} \mathrm{C} / 1 \mathrm{~d}\right)$ & $3.21 \pm 0.67$ \\
$\mathrm{E} 4\left(35^{\circ} \mathrm{C} / 1 \mathrm{~d}\right)$ & $4.01 \pm 0.80$ \\
$\mathrm{E} 5\left(7^{\circ} \mathrm{C} / 5.5 \mathrm{~d}\right)$ & $0.50 \pm 0.42$ \\
$\mathrm{E} 6\left(15^{\circ} \mathrm{C} / 5.5 \mathrm{~d}\right)$ & $3.32 \pm 0.43$ \\
$\mathrm{E} 7\left(20^{\circ} \mathrm{C} / 5.5 \mathrm{~d}\right)$ & $3.15 \pm 0.21$ \\
$\mathrm{E} 8\left(30^{\circ} \mathrm{C} / 5.5 \mathrm{~d}\right)$ & $3.66 \pm 0.61$ \\
$\mathrm{E} 9\left(4^{\circ} \mathrm{C} / 10 \mathrm{~d}\right)$ & $0.31 \pm 0.61$ \\
$\mathrm{E} 10\left(10^{\circ} \mathrm{C} / 10 \mathrm{~d}\right)$ & $1.16 \pm 0.95$ \\
$\mathrm{E} 11\left(25^{\circ} \mathrm{C} / 10 \mathrm{~d}\right)$ & $3.43 \pm 0.81$ \\
$\mathrm{E} 12\left(35^{\circ} \mathrm{C} / 10 \mathrm{~d}\right)$ & $4.43 \pm 0.77$ \\
\hline *Mean of three repetitions. &
\end{tabular}

\section{Analyses of the Contact Angles}

The contact angle with water $\left(\theta_{\mathrm{W}}\right)$ measured for $B$. cereus was lower than $50^{\circ}$, (Table 4) indicating that it is a hydrophilic surface according to the classification system proposed by Azeredo (1). According to this author, surfaces with a $\theta_{\mathrm{W}}$ less than $50^{\circ}$ are classified as hydrophilic, whereas surfaces with a 
$\theta_{\mathrm{W}}$ greater than $50^{\circ}$ are classified as hydrophobic. The stainless steel surfaces adhered by $B$. cereus at $20^{\circ} \mathrm{C} / 5.5 \mathrm{~d}$ and $10^{\circ} \mathrm{C} / 10$ d with $\theta_{\mathrm{W}}$ values lower than $50^{\circ}$ also were considered hydrophilic. The surfaces were evaluated in others conditions and were classified as hydrophobic. The stainless steel surface without cells adhered was hydrophobic. The contact angle with water is a qualitative criterion used to classify the hydrophobicity of food processing or microorganism surfaces. Faille et al. (7) found contact angles $\left(\theta_{\mathrm{W}}\right)$ for stainless steel of $75^{\circ}$, confirming the hydrophobic characteristics of this material.

\section{Thermodynamic Parameters of the Surfaces}

The contact angle measurements for the three substances were used to calculate the components of interfacial tension and levels of hydrophobicity (Table 5). It is possible to estimate the hydrophilic or hydrophobic character of the surfaces by components of interfacial tension. With increasing $\gamma^{\text {LW }}$ values, the apolarity of a surface increases, which results in lower affinity of that surface for polar liquids. A high $\gamma^{\mathrm{AB}}$ component value means more water of hydration on the surface and increased hydrophilicity. According to these criteria, $B$. cereus surfaces and stainless steel surfaces adhered by $B$. cereus at $10^{\circ} \mathrm{C} / 10 \mathrm{~d}$ are considered to hydrophilic because their $\gamma^{\mathrm{AB}}$ values are higher than those of the other surfaces. This result does not agree with those obtained by contact angle measurement with water $\left(\theta_{\mathrm{W}}\right)$ that also classified as hydrophilic the surfaces of stainless steel adhered by B. cereus at $20^{\circ} \mathrm{C} / 5.5$ d.

The component $\gamma-$ can also be a semi-quantitative measure of hydrophobicity $\gamma$ - values $\leq 25.5 \mathrm{~mJ} / \mathrm{m}^{2}$ indicate a hydrophobic surface regardless of the value of the apolar component. The $\gamma-$ values between $25 \mathrm{~mJ} / \mathrm{m}^{2}$ and $35 \mathrm{~mJ} / \mathrm{m}^{2}$ suggest that the hydrophobicity is dependent upon the apolar component. In these cases, the surfaces are hydrophilic when $\gamma^{\mathrm{LW}} \leq 45 \mathrm{~mJ} / \mathrm{m}^{2}$ and hydrophobic when $\gamma^{\mathrm{LW}} \geq 46 \mathrm{~mJ} / \mathrm{m}^{2}$ (1). According to the results, B. cereus is an electron donor because the $\gamma$ - values are higher than the $\gamma+$ values. Strevett and Chen (15) demonstrated that $\gamma-$ is always higher than $\gamma+$ for E. coli, P. fluorescens, B. subtilis and P. aeruginosa, confirming the electron donor characteristics of these bacterial cells. All biosurfaces are predominantly electron donors because of the presence of oxygen in the atmosphere and the hydration of microbial cells (18). Stainless steel surfaces not adhered by $B$. cereus also act as electron donors. Similar to our findings, Chaves (6) observed that the surface of stainless steel AISI 316 predominately acts as an electron, similar to most solid surfaces. Furthermore, B. cereus surfaces and stainless steel surfaces adhered by cells of B. cereus at $20^{\circ} \mathrm{C} / 5.5 \mathrm{~d}$ are considered hydrophilic because they did not present $\gamma-\leq 25.5$ $\mathrm{mJ} / \mathrm{m}^{2}$. The other surfaces, including stainless steel surfaces adhered by $B$. cereus at $10^{\circ} \mathrm{C} / 10 \mathrm{~d}$, are considered hydrophobic.

Table 4. Measurements of the contact angles $(\theta)$ of the cells of Bacillus cereus and stainless steel in the presence or absence of Bacillus cereus adherence with water $\left(\theta_{\mathrm{A}}\right)$, formamide $\left(\theta_{\mathrm{F}}\right)$ and $\alpha$-bromonaphthalene $\left(\theta_{\mathrm{B}}\right)$.

\begin{tabular}{llll}
\hline & \multicolumn{1}{c}{ Contact angles $\left.\mathbf{(}^{\mathbf{o}}\right)^{*}$} & $\boldsymbol{\Theta}_{\mathbf{F}}$ & $\boldsymbol{\Theta}_{\mathbf{B}}$ \\
\hline Stainless steel & \multicolumn{1}{c}{$\boldsymbol{\Theta}_{\mathbf{W}}$} & $53.36 \pm 9.4$ & $28.1 \pm 3.1$ \\
B. cereus & $70.77 \pm 7.9$ & $15.37 \pm 1.3$ & $45.17 \pm 0.5$ \\
E1 $\left(4^{\circ} \mathrm{C} / 1 \mathrm{~d}\right)$ & $24.52 \pm 2.8$ & $56.1 \pm 8.6$ & $34.6 \pm 6.7$ \\
E2 $\left(10^{\circ} \mathrm{C} / 1 \mathrm{~d}\right)$ & $72.1 \pm 2.6$ & $57.0 \pm 7.2$ & $30.5 \pm 5.9$ \\
E3 $\left(25^{\circ} \mathrm{C} / 1 \mathrm{~d}\right)$ & $73.2 \pm 0.5$ & $57.5 \pm 6.7$ & $25.3 \pm 6.7$ \\
E4 $\left(35^{\circ} \mathrm{C} / 1 \mathrm{~d}\right)$ & $57.3 \pm 11.9$ & $40.5 \pm 1.5$ & $32.0 \pm 3.5$ \\
E5 $\left(7^{\circ} \mathrm{C} / 5.5 \mathrm{~d}\right)$ & $60.1 \pm 10.5$ & $52.2 \pm 4.2$ & $35.6 \pm 4.7$ \\
E6 $\left(15^{\circ} \mathrm{C} / 5.5 \mathrm{~d}\right)$ & $69.6 \pm 1.4$ & $56.7 \pm 7.0$ & $32.2 \pm 4.3$ \\
E7 $\left(20^{\circ} \mathrm{C} / 5.5 \mathrm{~d}\right)$ & $56.7 \pm 10.7$ & $44.2 \pm 2.6$ & $39.0 \pm 7.3$ \\
E8 $\left(30^{\circ} \mathrm{C} / 5.5 \mathrm{~d}\right)$ & $49.3 \pm 6.1$ & $53.5 \pm 8.3$ & $34.5 \pm 0.2$ \\
E9 $\left(4^{\circ} \mathrm{C} / 10 \mathrm{~d}\right)$ & $73.7 \pm 5.0$ & $57.6 \pm 6.0$ & $33.6 \pm 6.7$ \\
$\mathrm{E} 10\left(10^{\circ} \mathrm{C} / 10 \mathrm{~d}\right)$ & $77.6 \pm 8.9$ & $19.2 \pm 3.2$ & $34.2 \pm 3.3$ \\
$\mathrm{E} 11\left(25^{\circ} \mathrm{C} / 10 \mathrm{~d}\right)$ & $48.9 \pm 14.8$ & $43.2 \pm 6.0$ & $31.5 \pm 1.6$ \\
$\mathrm{E} 12\left(35^{\circ} \mathrm{C} / 10 \mathrm{~d}\right)$ & $62.8 \pm 8.2$ & $39.4 \pm 11.9$ & $32.8 \pm 6.3$ \\
\hline
\end{tabular}

* Mean of three repetitions. 
Table 5. Values of the interfacial tension components $\left(\gamma^{\mathrm{LW}}, \gamma^{+}, \gamma^{-}, \gamma^{\mathrm{AB}}, \gamma^{\mathrm{TOT}}\right)$ of the cells of the Bacillus cereus, stainless steel and stainless steel adhered by cells of $B$. cereus.

\begin{tabular}{lccccc}
\hline \multicolumn{7}{c}{ Surfaces } & $\gamma^{\mathrm{LW}}$ & $\boldsymbol{\gamma}^{+}$ & $\boldsymbol{\gamma}^{-}$ & $\gamma^{\mathbf{A B}}$ & $\boldsymbol{\gamma}^{\mathrm{TOT}}$ \\
\hline Stainless steel & 39.3206 & 0.0899 & 6.3333 & 1.5091 & 40.8297 \\
B. cereus & 32.2682 & 3.2454 & 45.2929 & 24.2482 & 56.5164 \\
E1 $\left(4^{\circ} \mathrm{C} / 1 \mathrm{~d}\right)$ & 36.8944 & 0.0956 & 12.2929 & 2.1681 & 39.0625 \\
E2 $\left(10^{\circ} \mathrm{C} / 1 \mathrm{~d}\right)$ & 38.4688 & 0.0207 & 11.6946 & 0.9840 & 39.4528 \\
$\mathrm{E} 3\left(25^{\circ} \mathrm{C} / 1 \mathrm{~d}\right)$ & 40.2433 & 0.3842 & 0.4922 & 0.8697 & 41.1130 \\
$\mathrm{E} 4\left(35^{\circ} \mathrm{C} / 1 \mathrm{~d}\right)$ & 37.9096 & 1.0378 & 16.8009 & 8.3510 & 46.2606 \\
$\mathrm{E} 5\left(7^{\circ} \mathrm{C} / 5.5 \mathrm{~d}\right)$ & 36.4894 & 0.3478 & 12.4987 & 4.1699 & 40.6593 \\
$\mathrm{E} 6\left(15^{\circ} \mathrm{C} / 5.5 \mathrm{~d}\right)$ & 37.8335 & 0.1378 & 7.6388 & 2.0519 & 39.8854 \\
$\mathrm{E} 7\left(20^{\circ} \mathrm{C} / 5.5 \mathrm{~d}\right)$ & 35.0565 & 0.4573 & 32.1712 & 7.6712 & 42.7277 \\
$\mathrm{E} 8\left(30^{\circ} \mathrm{C} / 5.5 \mathrm{~d}\right)$ & 36.9345 & 0.3508 & 9.1703 & 3.5871 & 40.5216 \\
$\mathrm{E} 9\left(4^{\circ} \mathrm{C} / 10 \mathrm{~d}\right)$ & 37.2915 & 0.1260 & 7.6212 & 1.9598 & 39.2513 \\
$\mathrm{E} 10\left(10^{\circ} \mathrm{C} / 10 \mathrm{~d}\right)$ & 37.0542 & 3.3996 & 20.0995 & 16.5324 & 53.5866 \\
$\mathrm{E} 11\left(25^{\circ} \mathrm{C} / 10 \mathrm{~d}\right)$ & 38.0982 & 0.8236 & 15.1795 & 7.0715 & 45.1697 \\
$\mathrm{E} 12\left(35^{\circ} \mathrm{C} / 10 \mathrm{~d}\right)$ & 37.6033 & 1.1625 & 17.5686 & 9.0384 & 46.6417 \\
\hline
\end{tabular}

\section{Total Free Energy of Interaction $\left(\Delta \mathbf{G}_{\mathrm{sws}}{ }^{\text {TOT }}\right)$}

According to the quantitative criteria, the B. cereus strain and the stainless steel surfaces adhered by B. cereus at 20 ${ }^{\circ} \mathrm{C} / 5.5 \mathrm{~d}$ were considered hydrophilic because the $\Delta \mathrm{G}_{\mathrm{sws}}{ }^{\text {TOT }}$ values for both surfaces were $>0$ (Table 6). The other surfaces were hydrophobic $\left(\Delta \mathrm{G}_{\mathrm{sws}}{ }^{\text {TOT }}<0\right)$. Similar results were found using the semiquantitative $\gamma$ - value. However, these results are different from those determined by qualitative criteria using contact angles with water $\left(\theta_{\mathrm{w}}\right)$, which considered stainless surfaces adhered by $B$. cereus at $10{ }^{\circ} \mathrm{C} / 10 \mathrm{~d}$ as hydrophilic. The $\Delta \mathrm{G}_{\mathrm{sws}}{ }^{\mathrm{LW}}$ values are generally negative in the bacterial interactions, indicating the Lifshitz van der Waals forces are predominantly attractive, whereas the $\Delta \mathrm{G}_{\mathrm{sws}}{ }^{\mathrm{AB}}$ can be positive or negative, indicating repulsion or attraction, respectively (4). In our experiment, $\Delta \mathrm{G}_{\mathrm{sws}}{ }^{\mathrm{AB}}$ values indicated attraction for most of the surfaces evaluated (Table 6). Only the surfaces considered hydrophilic showed $\Delta \mathrm{G}_{\mathrm{sws}}^{\mathrm{AB}}>0$, demonstrating that hydrophobicity is predominantly determined by polar forces of attraction. The component $\Delta \mathrm{G}_{\mathrm{sws}}{ }^{\mathrm{AB}}$ represents the hydration degree of surfaces, which means that high $\Delta \mathrm{G}_{\mathrm{sws}}{ }^{A B}$ values equal low hydrophobicity of the surfaces. Therefore, the qualitative and quantitative criteria used to evaluate hydrophobicity showed a slight divergence from the results of the hydrophobicity of the surfaces of the stainless steel adhered by $B$. cereus at $10{ }^{\circ} \mathrm{C} / 10 \mathrm{~d}$ (Tables 4 and 6). For the other evaluations, the results for both criteria were in agreement. The B. cereus surface was classified as hydrophilic and stainless steel surfaces were classified as hydrophobic. A possible explanation for the hydrophilicity of stainless steel surfaces adhered by microorganisms as classified by quantitative criteria is the random distribution of the drops of water that were placed on the surfaces to measure the contact angles. These drops can be placed in regions with different concentrations of adhered cells. Therefore, the contact angles measurements can be related to the hydrophobicity of the stainless steel surfaces or the cells, reflecting the characteristics of only one surface.

\section{Global Free Energy of Adhesion ( $\left.\Delta \mathbf{G}_{\text {adhesion }}\right)$}

According to the thermodynamic theory of adhesion, if attractive forces are higher than repulsive forces, the interaction of short reach plays an important role in bacterial adhesion to surfaces. Such forces include polar and apolar interactions. Bacterial adhesion is favorable if the interactions lead to a decrease in the free energy of adhesion $\left(\Delta \mathrm{G}_{\text {adhesion }}<0\right)$ (6). In our experiment, the free energy of adhesion between stainless steel and B. cereus was positive $\left(\Delta \mathrm{G}_{\text {adhesion }}>0\right)($ Table 7), being thermodynamically unfavorable. This finding was 
similar those observed by Teixeira et al. (16), in which strains of Pseudomonas aeruginosa and Staphylococcus sciuri isolated from a milk machine were hydrophilic, the stainless steel surface was hydrophobic and the free energy of adhesion was positive. According to van Oss (20), it is well known that bacterial adhesion in an aqueous solution is favorable between hydrophobic surfaces, which can remove the water among them. However, it should be emphasized that adhesion between hydrophobic and hydrophilic surfaces or two hydrophilic surfaces can occur.

Table 6. Values of the apolar $\left(\Delta \mathrm{G}_{\mathrm{sws}}^{\mathrm{LW}}\right)$ and polar $\left(\Delta \mathrm{G}_{\mathrm{sws}}{ }^{\mathrm{AB}}\right)$ components of the total free energy of interaction $\left(\Delta \mathrm{G}_{\mathrm{sws}}{ }^{\text {TOT }}\right)$ of $B$. cereus surfaces and stainless steel surfaces in the presence or absence of $B$. cereus adherence.

\begin{tabular}{|c|c|c|c|}
\hline \multicolumn{4}{|c|}{ Total free energy of interaction $\left(\mathrm{mJ} / \mathrm{m}^{2}\right)$} \\
\hline & $\Delta \mathbf{G}_{\text {sws }}{ }^{L W}$ & $\Delta \mathbf{G}_{\mathrm{sws}}{ }^{\mathrm{AB}}$ & $\Delta \mathbf{G}_{\mathrm{sws}}{ }^{\mathrm{TOT}}$ \\
\hline Stainless steel & -5.1300 & -23.6028 & -28.7328 \\
\hline B. cereus & -2.0468 & 21.8664 & 19.8195 \\
\hline $\mathrm{E} 1\left(4{ }^{\circ} \mathrm{C} / 1 \mathrm{~d}\right)$ & -3.9462 & -29.2732 & -33.2194 \\
\hline $\mathrm{E} 2\left(10^{\circ} \mathrm{C} / 1 \mathrm{~d}\right)$ & -4.7024 & -31.9868 & -36.6892 \\
\hline $\mathrm{E} 3\left(25^{\circ} \mathrm{C} / 1 \mathrm{~d}\right)$ & -5.6075 & -77.0592 & -82.6668 \\
\hline $\mathrm{E} 4\left(35^{\circ} \mathrm{C} / 1 \mathrm{~d}\right)$ & -4.4238 & -15.3336 & -19.7574 \\
\hline $\mathrm{E} 5\left(7^{\circ} \mathrm{C} / 5.5 \mathrm{~d}\right)$ & -3.7673 & -27.0336 & -30.8009 \\
\hline $\mathrm{E} 6\left(15^{\circ} \mathrm{C} / 5.5 \mathrm{~d}\right)$ & -4.3900 & -42.7792 & -47.1692 \\
\hline $\mathrm{E} 7\left(20^{\circ} \mathrm{C} / 5.5 \mathrm{~d}\right)$ & -3.1313 & 10.8848 & 7.7535 \\
\hline $\mathrm{E} 8\left(30^{\circ} \mathrm{C} / 5.5 \mathrm{~d}\right)$ & -3.9668 & -36.0436 & -40.0104 \\
\hline $\mathrm{E} 9\left(4^{\circ} \mathrm{C} / 10 \mathrm{~d}\right)$ & -4.1335 & -42.9876 & -47.1211 \\
\hline $\mathrm{E} 10\left(10^{\circ} \mathrm{C} / 10 \mathrm{~d}\right)$ & -4.0224 & -7.2648 & -11.2872 \\
\hline $\mathrm{E} 11\left(25^{\circ} \mathrm{C} / 10 \mathrm{~d}\right)$ & -4.5199 & -19.1152 & -23.6351 \\
\hline $\mathrm{E} 12\left(35^{\circ} \mathrm{C} / 10 \mathrm{~d}\right)$ & -4.2813 & -13.6348 & -17.9161 \\
\hline
\end{tabular}

Table 7. Global free energy of adhesion values $\left(\Delta \mathrm{G}_{\text {adhesion }}\right)$ between Bacillus cereus $(\mathrm{b})$ and the stainless steel surfaces of AISI 304 (s) in aqueous liquid media (l) and their apolar $\left(\Delta \mathrm{G}_{\mathrm{bls}}{ }^{\mathrm{LW}}\right)$ and polar $\left(\Delta \mathrm{G}_{\mathrm{bls}}{ }^{\mathrm{AB}}\right)$ components.

\begin{tabular}{|c|c|c|c|}
\hline \multicolumn{4}{|c|}{ Global free energy of adhesion $\left(\mathrm{mJ} / \mathrm{m}^{2}\right)$} \\
\hline & $\Delta \mathbf{G}_{\mathrm{bls}} \mathbf{L W}$ & $\Delta \mathbf{G}_{\mathrm{bls}}{ }^{\mathrm{AB}}$ & $\Delta \mathbf{G}_{\text {adhesion }}$ \\
\hline B. cereus & -3.3353 & 5.8849 & 2.5496 \\
\hline
\end{tabular}

Despite that the strain studied in this experiment is considered hydrophilic, some strains of Bacillus can produces highly hydrophobic spores that are able to adhere strongly to stainless steel, a surface recognized as hydrophobic. After adhesion, the process of spore germination can occur and vegetative cells may colonize the surfaces (10).

\section{Roughness and Microtopography of the Surfaces}

There is no difference $(\mathrm{p} \geq 0.05)$ in the roughness of the surfaces analyzed by AFM and perfilometry (Figures 1 and 2). The increase of the number of adhered cells to surface coupons of stainless steel did not lead to an increase in surface roughness. These results can be explained due the low number of cells that adhered to the stainless steel in the different experiments, which reached approximately $10^{4} \mathrm{cfu} / \mathrm{cm}^{2}$. Thus, the measurements of roughness by AFM and perfilometry reflected the average roughness of the surface of the stainless steel.

According to Flint et al. (8), the relation between roughness and bacterial adhesion is not clear. This divergence is probably related to the degree of roughness studied, the bacterial strains tested, physicochemical characteristics of the surfaces and the method for detecting bacteria. Flint et al. (8) did not find a relationship between thermoresistant 
streptococcus adhesion to stainless steel and the roughness of surfaces. However, it was observed that maximum adhesion occurred with mean roughness values close to mean length of the bacteria $(0.9 \mu \mathrm{m})$. The authors suggested that some surface irregularities might provide protection to entrap cells in the cracks and crevices of the surface.

In 1 of 14 surfaces studied, a difference was observed between the qualitative criterion (contact angle measurement with water) and quantitative criterion $\left(\Delta \mathrm{G}_{\mathrm{sws}}{ }^{\text {тот }}\right.$ - total free energy of interaction) to evaluate the hydrophobicity of the surfaces. The free energy of adhesion between stainless steel AISI $304 \# 4$ and B. cereus was positive $\left(\Delta \mathrm{G}_{\text {adhesion }}>0\right)$, being therefore thermodynamically unfavorable. Thus, an interaction between them was not favorable according to the thermodynamic aspect of adhesion. There was no difference ( $p$ $\geq 0.05)$ in the roughness of the surfaces analyzed by AFM and perfilometry.

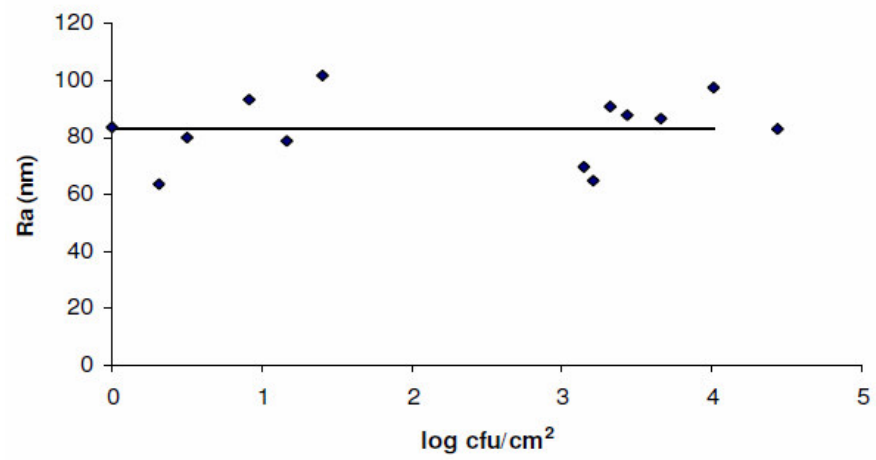

Figure 1. Means roughness $(\mathrm{Ra})$ of the stainless steel adhered with different number of cells of Bacillus cereus as evaluated by AFM.

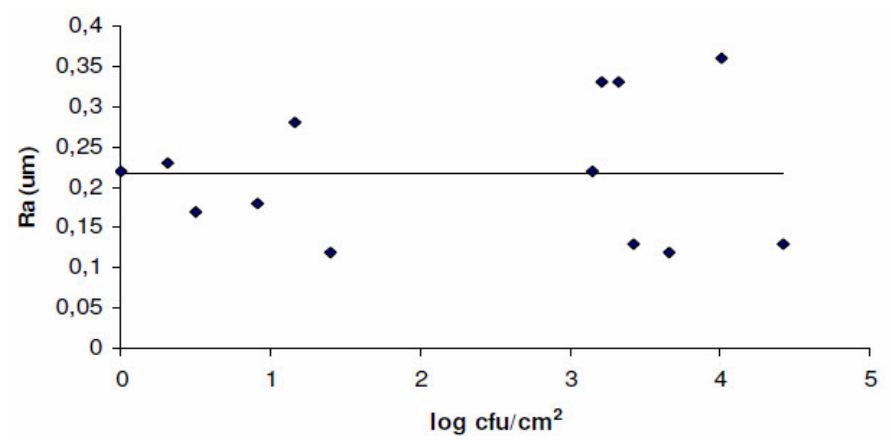

Figure 2. Means roughness ( $\mathrm{Ra}$ ) of the stainless steel adhered with different number of cells of Bacillus cereus as evaluated by Perthometer.

\section{REFERENCES}

1. Azeredo, J. (1998). Adesão de microrganismos e composição da matriz de bioagregados desenvolvimento de técnicas e estudo da influência de exopolímeros. Braga, Portugal, 231p. (D. Sc. Thesis. Departamento de Engenharia Biológica. Uminho).

2. Bartoszewicza, M.; Hansenb, B.M.; Swiecicka, I. (2008). The members of the Bacillus cereus group are commonly present contaminants of fresh and heat-treated milk. Food Microbiol. 25, 588-596.

3. Boor, K.J. (2001). ADSA foundation scholar award - fluid dairy product quality and safety: looking to the future. J. Dairy Sci. 84, 1-11.

4. Bos, R.; Van Der Mei, H.C.; Busscher, H.J. (1999). Physico-chemistry of initial microbial adhesive interactions - its mechanisms and methods for study. FEMS Microbiol. Rev. 23, 79-230.

5. Busscher, H.J.; Weerkamp, A.H.; Van Der Mei, H.C.; Van Pelt, A.W.; Jong, H.P.; Arends, J. (1984). Measurement of the surface free energy of bacterial cell surface and its relevance for adhesion. Appl. Environ. Microbiol. 48 (5), 980-983.

6. Chaves, L.C.D. (2004). Estudo da cinética da formação de biofilmes em superfícies em contato com água potável. Braga, Portugal, 156 p. (M. Sc. Dissertation. Departamento de Engenharia Biológica. Uminho).

7. Faille, C.; Fontaine, F.; Bénézech, T. (2001). Potencial occurrence of adhering living Bacillus spores in milk product processing lines. J. Appl Microbiol. 90, 892-900.

8. Flint, S.H.; Brooks, J.D.; Bremer, P.J. (2000). Properties of the stainless steel substrate, influencing the adhesion of thermo-resistant streptococci. J.Food Eng. 43, 235-242.

9. Fromm, H.I.; Boor, K.J. (2004). Characterization of pasteurized fluid milk shelf-life attributes. J. Food Sci. 69 (8), 207-214.

10. Hüsmark, U.; Rönner, U. (1992). The influence of hydrophobic, electrostatic and morphologic properties on the adhesion of Bacillus spores. Biofoul. 5, 335-344.

11. Larsen, H.D.; Jørgensen, K. (1997). The occurrence of Bacillus cereus in Danish pasteurized milk. Int. J. Food Microbiol. 34, 179-186.

12. Parizzi, S.Q.F.; Andrade, N.J.; Soares, N.F.F.; Silva, C.A.S.; Monteiro, E.A.M. (2004). Bacterial adherence to different inert surfaces evaluated by epifluorescence microscopy and plate count method. Braz. Arch. Biol. Technol. 47 (1), 77-83.

13. Peng, J.S.; Tsai, W.C.; Chou, C.C. (2002). Inactivation and removal of Bacillus cereus by sanitizer and detergent. Int. J. Food Microbiol. 77,1118.

14. Reyes, J.E.; Bastías, J.M.; Gutiérrez, M.R.; Rodríguez, M.O. (2007). Prevalence of Bacillus cereus in dried milk products used by Chilean School Feeding Program. Food Microbiol. 24, 1-6.

15. Strevett, K.A.; Chen, G. (2003). Microbial surface thermodynamics and applications. Res. Microbiol. 154, 329-335.

16. Teixeira, P.; Lopes, Z.; Azeredo, J.; Oliveira, R.; Vieira, M.J. (2005). Physico-quimical surface characterization of a bacterial population isolated from milking machine. Food Microbiol. 22, 247-251. 
17. Valcarce, M.B.; Busalmen, S.R.; Sánchez, S.R. (2002). The influence of the surface condition on the adhesion of Pseudomonas fluorescens (ATCC 17552) to copper and aluminium brass. Int. Biodeter. Biodeg. 50, 61-66.

18. Van Der Mei, H.C.; Bos, R.; Busscher, H.J. (1998). A reference guide to microbial cell surface hydrophobicity base don contact angles. Coll.
Surfac. 11, 213-221.

19. Van Oss, C.J. (1994). Interfacial Forces in Aqueous Media. Marcel Dekker Inc, New York, N.Y.

20. Van Oss, C.J. (1997). Hydrophobicity and hydrophilicity of biosurfactants. Curr. Opin. Coll. Int. Sci. 2, 503-512. 